\title{
PEMANFAAT MEDIA BOOKLET TERHADAP PENINGKATAN PENGETAHUAN IBU MENYUSUI TENTANG PIJAT OKSITOSIN
}

\author{
Ria Gustirini \\ Fakultas Ilmu Kesehatan Program Studi D III Kebidanan IKesT Muhammadiyah Palembang \\ riagustirini@gmail.com
}

\begin{abstract}
Breast milk production in the first days of childbirth becomes an obstacle for mothers in breastfeeding. Oxytocin massage is one way to overcome the improper production of breast milk. Knowledge or cognitive is a very important domain in shaping one's actions (ovent behavior). Health education can use various media, one of which is through the use of booklets. The aims: to analyze the effect of using booklet media on breastfeeding mothers' knowledge about oxytocin massage. The Method: This research was a quasiexperimental study using a pre test and posttest control design. Sampling in this study using purposive sampling technique. Some postpartum mothers who gave birth in JanuaryMay 2020 and met the inclusion criteria for a sample of 30 respondents who were divided into the treatment group and the control group. The statistical test used the independent $t$ test. Results: The results showed that there was a significant difference in increasing knowledge about oxytocin massage between the group that was given a booklet (treatment) and the group that was not given a booklet (control) with $p$ value <0,05. Conclusion: The role of a midwife as a professional is indispensable in providing health education so that the use of various media as a means of conveying information is needed to increase maternal knowledge
\end{abstract}

Keywords: breastfeeding mother, booklet, knowledge

\section{PENDAHULUAN}

Angka Kematian Bayi (AKB) di Indonesia masih tergolong tinggi dibandingkan Negara lain, Penyebab utama kematian bayi dan balita adalah diare dan pneumonia, lebih dari $50 \%$ kematian bayi dan balita ini disebabkan oleh kurangnya gizi. Pemberian ASI secara eksklusif selama 6 bulan dan diteruskan selama 2 tahun disamping pemberian makanan pendamping ASI (MPASI) secara adekuat terbukti sebagai salah satu intervensi efektif dapat menurunkan angka kematian bayi.(Astari \& Rahman; Gustirini, 2018).

ASI Eksklusif menurunkan angka kematian karena infeksi sebanyak $88 \%$ pada bayi berusia kurang dari 3 bulan. Lebih jauh lagi beberapa studi menyebutkan bahwa dalam upaya pencegahan berat bayi lahir rendah (BBLR), stunting dan meningkatkan inisiasi menyusui dini (IMD) dan ASI
Eksklusif berkontribusi dalam menurunkan risiko obesitas dan penyakit kronis. Menyusui tidak hanya menurunkan angka kematian bayi, tetapi juga dapat menurunkan risiko kegemukan hingga $10 \%$ (Lancet, 2016).

Produksi ASI pada hari-hari pertama melahirkan menjadi kendala bagi ibu dalam pemberian ASI. Pijat Oksitosin merupakan salah satu cara untuk mengatasi ketidaklancaran produksi ASI. Sedangkan hubungan antara perkembangan bayi dan pemberian ASI telah banyak diteliti. Kekurangan gizi yang terjadi pada awal kehidupan dapat mengakibatkan terjadinya growth faltering (gagal tumbuh) sehingga bayi akan tumbuh menjadi anak yang lebih pendek dari normal. Selain itu, kekurangan gizi juga dapat berpengaruh terhadap perkembangan kognitif, morbiditas dan mortalitas bayi.(Prabasiwi, Fikawati, \& Syafiq, 2015). 
Pijat oksitosin dilakukan untuk merangsang refleks oksitosin atau reflex let down. Dengan dilakukan pemijatan ini ibu akan merasa rileks, kelelahan setelah melahirkan akan hilang, sehingga dengan begitu hormon oksitosin keluar dan ASI pun cepat keluar. Manfaat tentang pijat oksitosin sudah dibuktikan melalui penelitian ilmiah. Berdasarkan penelitian yang telah dilakukan, terdapat pegaruh pijat oksitosin pada ibu postpartum terhadap produksi ASI yang dibuktikan dengan meningkatnya berat badan bayi (Gustirini \& Anggraini, 2020; Mardiyaningsih \& Sabri, 2011).

Pengetahuan merupakan hasil dari tahu, dan ini terjadi setelah orang melakukan penginderaan terhadap suatu objek tertentu. Penginderaan terjadi melalui pancaindera manusia yakni indra penglihatan, pendengaran, penciuman, rasa dan raba. Sebagian besar pengetahuan manusia diperoleh melalui mata dan telinga (Notoatmodjo, 2010).

Pengetahuan atau kognitif merupakan domain yang sangat penting dalam membentuk tindakan seseorang (ovent behavior). Pemberian ASI masih rendah dikarenakan persepsi ASI ibu sedikit sehingga menyebabkan ibu menghentikan pemberian ASI dan hal ini merupakan alasan utama untuk berhenti memberikan ASI (Ahluwalia, Morrow, \& Hsia, 2005).

Pendidikan kesehatan dapat menggunakan berbagai media, salah satunya adalah melalui menggunaan booklet. Tujuan penelitian ini adalah untuk menganalisis pengaruh pemanfaatan media booklet terhadap pengetahuan ibu menyusui tentang pijat oksitosin

\section{METODE PENELITIAN}

Penelitian ini merupakan penelitian quasi eksperimen dengan rancangan pre test and posttest control design. Pengambilan sampel dalam penelitian ini menggunakan teknik purposive sampling. Sampel dalam penelitian ini adalah sebagian ibu postpartum yang melahirkan pada bulan januari - Mei 2020 di PMB Nurachmi Kota Palembang serta memenuhi kriteria inklusi. sampel sebesar 30 responden yang dibagi dalam kelompok perlakuan yaitu kelompok yang mendapatkan booklet tentang pijat oksitosin dan kelompok kontrol yaitu kelompok yang tidak mendapatkan booklet tentang pijat oksitosin. Adapun kriteria inklusi sebagai berikut:

a. Ibu Post Partum 40 hari pertama

b. Ibu melahirkan normal di Bidan praktik mandiri

c. Ibu bisa membaca dan menulis

d. Ibu bersedia mengisi kuesioner pretest dan post test.

Kriteria Eksklusi adalah:

a. Ibu postpartum yang tidak bisa membaca dan menulis

b. Ibu postpartum yang tidak bersedia menjadi responden

Responden diminta kesediaannya untuk ikut serta dalam penelitian dengan menandatangani formulir informed consent Kemudian peneliti memberikan kuesioner pretest tentang pijat oksitosin untuk dikerjakan dalam waktu 30 menit. Setelah pretest selesai dikerjakan, ibu postpartum pada kelompok perlakuan akan diberikan booklet tentang pijat okitosin yang meliputi pengertian, tujuan, manfaat dan langkahlangkah pijat oksitosin kepada ibu postpartum. Sedangkan responden pada kelompok kontrol tidak diberikan booklet. Kuesioner pretest dan posttest merupakan kuesioner yang sama dan dikerjakan dengan alokasi waktu 30 menit.

\section{HASIL DAN PEMBAHASAN}

Penelitian telah dilakukan terhadap 30 responden yang memenuhi kriteria inklusi dan ekslusi yang terdiri dari dua kelompok. Kelompok perlakuan merupakan responden yang diberikan booklet tentang pijat oksitosin sedangkan kelompok kontrol merupakan responden yang tidak diberikan booklet tentang pijat oksitosin.

Hasil pengujian pemanfaatan media booklet terhadap pengetahuan ibu menyusui tentang pijat oksitosin sebagai berikut:

a. Karakteristik Responden Pada Kedua

Kelompok Penelitian

Tabel 1 Karakteristik Responden Pada Kedua Kelompok Penelitian

\begin{tabular}{|c|c|c|c|}
\hline \multirow{3}{*}{ Karakteristik } & \multicolumn{2}{|c|}{ Kelompok penelitian } & \multirow{3}{*}{ Nilai p } \\
\hline & Perlakuan & Kontrol & \\
\hline & $(n=15)$ & $(n=15)$ & \\
\hline Usia (th) & & & $0.938^{*}$ \\
\hline $\mathrm{x}(\mathrm{SD})$ & $26(3,2)$ & $25,9(3,7)$ & \\
\hline Rentang & $21-31$ & $21-32$ & \\
\hline Pendidikan & & & $0,714^{* *}$ \\
\hline $\mathrm{SD}$ & 2 & 2 & \\
\hline
\end{tabular}




\begin{tabular}{lccc}
\hline SMP & 7 & 7 & \\
SMA & 9 & 11 & \\
PT & 4 & 3 & $1,000^{* * *}$ \\
Pekerjaan & & & \\
Bekerja & 7 & 8 & \\
Tidak Bekerja & 8 & 7 & \\
Pengetahuan & & & \\
(Pretest) & & & \\
Rerata (SD) & $52,7(10,3)$ & $54(8,3)$ & $0,700^{*}$ \\
Rentang & $30-70$ & $40-70$ & \\
\hline Keto
\end{tabular}

Pengetahuan seseorang dapat meningkat disebabkan penyerapan informasi yang baik. Pengetahuan yang baik, akan membentuk persepsi yang baik juga. Pada penelitian ini tidak terdapat perbedaan yang bermakna pada skore / nilai pre test antara kelompok perlakuan dan kelompok kontrol ( $\mathrm{p}>0,05)$.

Keterangan uji: ")Berdasarkan Uji T Independent ${ }^{* * *}$ ) b. Pengaruh Pemanfaatan Media Booklet Chi-Square, ${ }^{* * * *}$ ) Fisher Exact

Tabel 1 menunjukkan tidak terdapat perbedaan yang bermakna pada karakteristik responden meliputi usia ibu, pendidikan, pekerjaan, dan pengetahuan tentang pijat oksitosin sebelum diberikan perlakuan antara kelompok perlakuan dan kelompok kontrol( $\mathrm{p}>0,05)$.

Pemberian ASI eksklusif pada bayi selama enam bulan pertama telah direkomendasikan WHO dan Nations International Children's Emergency Fund (UNICEF) sebagai salah satu strategi global pemberian makanan pada bayi.(Organization, 2009) ASI merupakan sumber ideal bagi bayi terutama 6 bulan pertama kehidupannya(Marques, Lopez, \& Braga, 2004) karena ASI merupakan sumber lemak dan protein yang penting bagi pertumbuhan dan nutrisi bayi.(Neville \& Morton, 2001).

Capaian ASI eksklusif di Indonesia masih jauh dari target nasional yaitu sebesar $80 \%$. Persentase pemberian ASI eksklusif pada bayi 0-6 bulan di Indonesia pada tahun 2013 sebesar 54,3\%.(Indonesia, 2014) Produksi ASI pada hari-hari pertama melahirkan menjadi kendala bagi ibu dalam pemberian ASI. Pijat Oksitosin merupakan salah satu cara untuk mengatasi ketidaklancaran produksi ASI.

Pendidikan mempengaruhi proses belajar, semakin tinggi pendidikan seseorang semakin mudah menyerap informasi yang diberikan. Tingkat pendidikan yang tinggi memberikan kesadaran tentang pijat oksitosin untuk meningkatkan produksi ASI. Pada penelitian ini, tidak terdapat perbedaan yang bermakna pada pendidikan ibu antara kelompok perlakuan dan kelompok kontrol ( $p>0,05)$.(Zulfatunnisa \& Dewi, 2020).

Tentang Pijat Oksitosin

Peningkatan pengetahuan pre dan post antar kedua kelompok penelitian sebagai berikut:

Tabel 2. Peningkatan Pengetahuan Pre dan Post pada Kedua Kelompok Penelitian

\begin{tabular}{lccc}
\hline & \multicolumn{2}{c}{ Kelompok penelitian } & Nilai \\
\cline { 2 - 3 } Variabel & Perlakuan & Kontrol & p \\
\cline { 2 - 3 } & $\mathbf{( n = 1 5 )}$ & $\mathbf{( n = 1 5 )}$ & \\
\hline Peningkatan & & & \\
Pengetahuan & & & \\
Rerata (SD) & $26(14)$ & $12(18)$ & 0,026 \\
Rentang & $0-60$ & $(-30)-40$ & \\
\hline
\end{tabular}

Keterangan uji: Berdasarkan Uji T Independent

Tabel 2 menunjukkan terdapat perbedaan yang bermakna pada peningkatan pengetahuan tentang pijat oksitosin antara kelompok yang diberikan booklet (perlakuan) dan kelompok yang tidak diberikan booklet (kontrol) dengan nilai $\mathrm{p}<0,05$.

Hari-hari pertama melahirkan menjadi kendala bagi ibu dalam pemberian ASI. Kurangnya produksi ASI pada minggu pertama setelah melahirkan disebabkan oleh kurangnya rangsangan hormon prolaktin dan oksitosin yang sangat berperan dalam kelancaran produksi dan pengeluaran ASI. Pijat oksitosin merupakan salah satu teknik untuk mengatasi ketidaklancaran produksi ASI. Pijat oksitosin adalah pemijatan pada sepanjang tulang belakang (vertebrae) sampai tulang costae kelima-keenam dan merupakan usaha untuk merangsang hormon oksitosin.(Gustirini \& Anggraini, 2020).

Pengetahuan atau kognitif merupakan domain yang sangat penting dalam membentuk tindakan seseorang (ovent behavior). Pemberian ASI masih rendah dikarenakan persepsi ASI ibu sedikit sehingga menyebabkan ibu menghentikan pemberian ASI dan hal ini merupakan 
alasan utama untuk berhenti memberikan ASI. Pendidikan kesehatan dapat menggunakan berbagai media, salah satunya adalah melalui penggunaan booklet.

Tabel 2 menunjukkan terdapat perbedaan yang bermakna pada peningkatan pengetahuan tentang pijat oksitosin antara kelompok yang diberikan booklet (perlakuan) dan kelompok yang tidak diberikan booklet (kontrol) dengan nilai $\mathrm{p}<0,05$. Nilai rata-rata peningkatan pengetahuan responden tentang pijat oksitosin sebelum dan setelah diberikan booklet yaitu sebesar 26 poin dengan rentang peningkatan yaitu 0-60 poin. Sedangkan pada kelompok kontrol ( tidak diberikan booklet) terdapat nilai rata-rata peningkatan pengetahuan tentang pijat oksitosin sebesar 12 poin dengan rentang peningkatan (-30)-40 poin.

Pada kelompok yang kontrol (tidak diberikan booklet) terdapat penurunan nilai post test. Hal ini dapat terjadi karena pada kelompok kontrol tidak dilakukan penyampaian informasi seperti pada kelompok perlakuan, sehingga responden tidak mendapatkan informasi yang benar tentang pijat oksitosin, hal ini berpengaruh terhadap pengisian kuesioner. Sedangkan pada kelompok perlakuan, responden mendapatkan informasi yang lengkap tentang pijat oksitosin melalui media booklet.

Booklet adalah buku tipis yang mudah dibawa, memuat informasi yang lengkap, jelas, mudah dimengerti, berisi tulisan dan gambar.(Agustin, Kep, Ns, Susilaningsih, $\&$ KP, 2014) Booklet yang diberikan pada kelompok perlakuan berisi tentang informasi yang lengkap tentang pijat oksitosin mencakup pengertian, tujuan dilakukan pijat oksitosin, manfaat dan langkah-langkah pijat oksitosin. Booklet tersebut juga disertai dengan gambar yang menarik sehingga responden tertarik untuk membaca booklet tersebut.

Pengetahuan seseorang dapat meningkat disebabkan penyerapan informasi yang baik semakin tinggi tingkat pengetahuan dan pemahaman terhadap kesehatan, akan meningkat pula cara pandang terhadap konsep sehat dan sakit menjadi mantap yang pada akhirnya akan mempengaruhi pandangan, cara hidup dan upaya seseorang untuk dapat menigkatkan derajat kesehatan. Pijat oksitosin ini merupakan hal yang baru dan masing jarang diterapkan di masyarakat (Zulfatunnisa \& Dewi, 2020).

Hasil penelitian ini sejalan dengan penelitian sebelumnya dimana pendidikan kesehatan yang disampaikan dengan media booklet dapat berpengaruh signifikan dalam meningkatkan pengetahuan. Pengetahuan yang baik perlahan-lahan akan membentuk perilaku yang positif sehingga pemilihan pendidikan yang efektif diperlukan untuk mencapai tujuan yang maksimal.(Ma'munah, 2015)

Media booklet mempunyai kelebihan dari media lainnya karena dapat disajikan lebih lengkap, dapat disimpan lama, mudah dibawa dan dapat memberikan isi informasi yang lebih detail yang mungkin belum didapatkan saat disampaikan secara lisan. Hal ini sejalan dengan penelitian sebelumnya dimana pendidikan kesehatan menggunakan media booklet lebih berpengaruh terhadap peningkatan pengetahuan responden disbanding menggunakan media leaflet.(Artini, Maliya, \& Sudaryanto, 2014)

Penelitian ini juga sejalan dengan penelitian sebelumnya dimana media booklet dan audiovisual sama-sama efektif dapat meningkatkan pengetahuan tentang karier gigi. Informasi dan pengalama pribadi merupakan faktor yang mempengaruhi pengetahuan. Berkembangnya teknologi akan menyediakan berbagai media yang dapat mempengaruhi pengetahuan masyarakat (Agustin et al., 2014).

\section{KESIMPULAN}

Berdasarkan hasil penelitian didapatkan bahwa terdapat perbedaan yang bermakna pada peningkatan pengetahuan tentang pijat oksitosin antara kelompok yang diberikan booklet (perlakuan) dan kelompok yang tidak diberikan booklet (kontrol) dengan nilai $\mathrm{p}<0,05$.

Peran aktif bidan sebagai tenaga profesional sangat diperlukan dalam memberikan konseling, informasi dan 
edukasi tentang pijat oksitosin melalui media yang menarik dan komunikatif seperti menggunakan media booklet kepada ibu menyusui serta bidan diharapkan dapat menjelaskan langkah-langkah melakukan pijat oksitosin yang benar sampai ibu dan keluarga mengerti, memahami, dan mampu melakukannya secara mandiri dirumah.

\section{REFERENSI}

Agustin, Maria, Kep, Irdawati S, Ns, Msi, Susilaningsih, Endang Zulaicha, \& KP, S. (2014). Efektifitas Pendidikan Kesehatan Media Booklet Dibandingkan Audiovisual Terhadap Pengetahuan Orang Tua Tentang Karies Gigi Pada Anak Usia 5-9 Tahun Di Desa Makamhaji. Universitas Muhammadiyah Surakarta.

Ahluwalia, Indu B, Morrow, Brian, \& Hsia, Jason. (2005). Why do women stop breastfeeding? Findings from the Pregnancy Risk Assessment and Monitoring System. Pediatrics, 116(6), 1408-1412.

Artini, Friza Rahmi, Maliya, Arina, \& Sudaryanto, Agus. (2014). Perbedaan Pengaruh Pendidikan Kesehatan Menggunakan Media Leaflet dengan Booklet terhadap Tingkat Pengetahuan Masyarakat tentang Chikungunya di Desa Trangsan Gatak Sukoharjo. Universitas Muhammadiyah Surakarta.

Astari, Ruri Yuni, \& Rahman, Recxa Agtarika Intanpuri Nur. FaktorFaktor Yang Berhubungan Dengan Pemberian Asi Eksklusif Pada Ibu Bekerja Di Wilayah Kerja Uptd Puskesmas Kertajati Kabupaten Majalengka TAHUN 2017.

Gustirini, Ria. (2018). Hubungan Antara Berat Badan Lahir Bayi Dengan Waktu Terjadinya Lactogenesis Ii Pada Ibu Postpartum. Masker Medika, 6(2), 472-479.

Gustirini, Ria, \& Anggraini, Inge Anggi. (2020). Combination Of Breast Care And Oxytocin Massage Of
Breastfeeding Mothers In Infant Weight Gain. Jurnal Kesehatan Prima, 14(1), 24-30.

Indonesia, Kementerian Kesehatan Republik. (2014). Profil Kesehatan Indonesia 2013

Lancet, The. (2016). Breastfeeding: achieving the new normal: Elsevier.

Ma'munah, Malikatul. (2015). Pengaruh Pendidikan Kesehatan Dengan Booklet Terhadap Pengetahuan Ibu Laktasi Di Wilayah Kerja Puskesmas Ciputat Timur. UIN Syarif Hidayatullah Jakarta: Fakultas Kedokteran Dan Ilmu Kesehatan, 2015.

Mardiyaningsih, Eko, \& Sabri, Luknis. (2011). Efektifitas kombinasi teknik marmet dan pijat oksitosin terhadap produksi asi ibu post seksio di rumah sakit wilayah Jawa Tengah. Jurnal Keperawatan Soedirman, 6(1), 31-38.

Marques, Rosa FSV, Lopez, Fábio A, \& Braga, Josefina AP. (2004). Growth of exclusively breastfed infants in the first 6 months of life. Jornal de pediatria, 80(2), 99-105.

Neville, Margaret C, \& Morton, Jane. (2001). Physiology and endocrine changes underlying human lactogenesis II. The Journal of nutrition, 131(11), 3005S-3008S.

Notoatmodjo, Soekidjo. (2010). Ilmu perilaku kesehatan. Jakarta: rineka cipta, 200, 26-35.

Organization, World Health. (2009). Infant and young child feeding: model chapter for textbooks for medical students and allied health professionals.

Prabasiwi, Adila, Fikawati, Sandra, \& Syafiq, Ahmad. (2015). ASI eksklusif dan persepsi ketidakcukupan ASI. Kesmas: National Public Health Journal, 9(3), 282-287.

Zulfatunnisa, Nevia, \& Dewi, Wiwik Puspita. (2020). Hubungan Tingkat Pendidikan Dengan Pengetahuan Primipara Tentang Manfaat Pijat 


\section{\begin{tabular}{|l|l|} 
Jurnal Delima Harapan & 2021
\end{tabular}}

Oksitosin Di Puskesmas Sibela

Mojosongo. Profesi (Profesional

Islam): Media Publikasi Penelitian,

17(2), 43-50. 